\title{
Forest Inventory using Optical and Radar Remote Sensing
}

\author{
Yolanda Fernández-Ordóñez ${ }^{1}$, Jesús Soria-Ruiz² and Brigitte Leblon ${ }^{3}$ \\ 1 Postgraduate College in Agricultural Sciences (COLPOS), Mexico \\ ${ }^{2}$ National Institute of Research for Forestry, Agriculture and Livestock (INIFAP), Mexico \\ ${ }^{3}$ Faculty of Forestry and Environmental Management, University of New Brunswick,
}

Canada

\section{Introduction}

Forests cover approximately a third of the planet's land area, and range from undisturbed primary forests to forests managed and used for a variety of purposes. Using forests as a resource has an impact on the environment and on the economies of nations. Forests have a history of being exploited either adequately or abusively, but more efforts are now being made towards their sustainable use. The assessment of forests in terms of their extent, condition, use, and value is periodically realized at both global and country levels (Ridder, 2007). Applications relating to the monitoring of forest status and to forest management require updated and accurate inventories summarizing knowledge of land use changes related to forests, including the rates and patterns of deforestation and afforestation. This knowledge must bear more detail for use at regional and local scales. Inventories are produced in most countries at various levels and various update periodicities. The survey methods and technologies applied in each case vary according to the intended use, inherent costs, timeliness, and desired accuracy of the inventory. Sustainable Forest Management (SFM) aims to manage forest land in order to obtain products and services while simultaneously minimising any undesirable effects on the social and physical environments. Major issues concerning SFM include establishing the location, extent, volume, and status of different forest types such as permanent forest estates managed for timber, areas susceptible to reconversion, and protected areas where logging and extracting activities are to be strictly controlled (ITTO, 2006). Forest volume inventories provide valuable data for estimating above-ground biomass density and carbon stores (Zheng et al., 2007). Good estimates of forest biomass are relevant in monitoring deforestation and forest degradation, which impact the global carbon cycle (Haripriya, 2000; DeFries et al., 2006).

Traditionally aerial photographs have been used for forest inventories, but their availability and area coverage can be limited. A promising alternative is the use of images acquired by space borne sensors. Satellite images used in forest inventory were first provided by optical sensors, but their availability is still limited because their acquisition depends on solar radiation. More recently, synthetic aperture radar (SAR) imaging systems were developed. They are active sensors that produce their own incident radiation and thus are able of 
acquiring images whatever the weather and illumination conditions. The wavelength they used is also longer than the one of the optical sensors, allowing measuring different characteristics of the imaged area.

Thus optical and radar remote sensing (RS) provide different but complementary capabilities for estimates of general forest status such as crown height, density and shape, tree basal area, timber volume and biomass. For forest inventory some variables would be more useful per se than others where composition at the species level becomes relevant. Therefore, approaches that combine information obtained from multiple sources offer a promising approach towards establishing more accurate and detailed land cover inventories, particularly at regional and local levels.

This chapter is concerned with forest inventory mapping using combinations of optical and radar RS techniques and intervening field studies at cartographic scales $(1: 20,000)$ applicable to regional and local forest management. These themes are examined with respect to providing insights into the use of combined RS techniques for more comprehensive, costeffective, and accurate forest inventories particularly in Mexico, a mega-diverse country with an increasing concern for the conservation of its biodiversity and sustainable natural resources management (Conservation International, 2008).

In the following two sections, a review of optical and radar RS as they pertain to forest inventory is presented. Then follows a section on the combination and fusion of optical and radar RS data. Ongoing and future work which aim at applying these techniques using medium and high resolution optical imagery and radar imagery in Central Mexico are described next. A paragraph on conclusions and foreseeable developments closes this chapter. The list of references is included.

\section{Optical RS}

Global and regional forest mapping are increasingly relying on optical RS because of the lower cost of gathering synoptic forest data. Traditional sampling methods can be costly or inapplicable due to terrain topography or field work resources and costs (Shiver and Borders, 1996). Optical sensors use wavelengths from 0.4 to $2.5 \mu \mathrm{m}$ to measure reflected solar radiation. The range of the visible radiation, from 0.4 to $0.7 \mu \mathrm{m}$, also termed photosynthetically active radiation (PAR), is useful for the detection of plant photosynthesis. Visible, near-red, and infra-red wavelengths used for data imaging are of the same order of magnitude as the cell components and prevailing pigments of plants, so a variety of techniques have been established for determining tree canopy biochemistry and for deriving plant condition.

Space-borne optical sensors are passive or active, depending on the solar radiation. Data acquisition is affected by illumination conditions and is subject to atmospheric absorption and scattering, due to the applicable wavelength which is of the same order of magnitude as the size of atmospheric constituents (Gerstl, 1990). Over the years, research has provided knowledge on how various factors, such as tree foliage type and understorey vegetation, impact reflectance data in the visible, near-infrared, and infrared bands (Myneni et al., 1995). The passive satellite-borne sensor applications have focused mainly on mapping biophysical and biogeochemical information from multi-spectral images. More recently airborne optical active sensors called LiDAR that send their own incident energy have been developed. They are increasingly being used for forest applications mainly for estimating tree height, crown 
dimensions, canopy height of stands and canopy cover. LiDAR is not further discussed here because there is not yet an operational space-borne LiDAR sensor, and the reader is referred to recent review works which show the potential advantages of this type of sensor (Sun \& Ranson, 2000); (Packalén and Mantamo, 2008).

Passive optical RS applications for forestry inventories are based on the sensitivity of optical radiation to the chlorophyllian content of the stands as detailed in Leblon (1997). However several factors can interfere such as the optical properties of the soil background, illumination and viewing geometries as well as from meteorological factors (wind, cloud). To reduce the effect of these factors on the forest canopy spectral response, single-band reflectances measured by the sensors are generally combined into vegetation indices. At least fifty different vegetation indices exist (Bannari et al., 1995). The most commonly used vegetation indices are ratios of single-band or linear-combined reflectances. Ratioing allows removal of the disturbances affecting, in the same way, reflectance in each band. As a spectral band, most ratio-based vegetation indices use either the red band, which is related to the chlorophyll light absorption or the near-infrared band, which is related to the green vegetation density. Indeed, both bands contain more than $90 \%$ of the spectral information of a plant canopy. Also, in red and near-infrared bands, the contrast between vegetation and bare soil is at a maximum. Other indices based on the short-wave infrared have been developed that are sensitive more to the moisture content of the canopy than to its chlorophyll content. It has been shown that these indices better estimated the density of managed conifer forests than those sensitive to chlorophyll (Aguirre-Salado et al., 2009).

When using optical RS images in forest inventory mapping, one should pay attention to characteristics of the phenological cycle which are directly related to both vegetation type and species diversity and thus indirectly to small-scale heterogeneity of climatic and topographic conditions in the corresponding study region. Therefore a key component for forest attribute determination is the time-series analysis of repetitive multispectral and even hyperspectral imagery (Vuolo et al., 2008; Schowengerdt, 1997).

In addition to this time dimension, one also needs to consider the spatial dimension. High spatial resolution images such as Ikonos and Quickbird provide better estimates for tree crown cover over medium resolution images from SPOT and Landsat sensors in the case of pine forests. A small scale experiment has shown that there is confusion with tree shadows when using medium resolution optical imagery, which is a drawback for forested areas in ravines or over steep slopes (Valdez-Lazalde et al., 2009). Approaches to overcome this and other drawbacks include multi-angle optical RS whereby separating sunlit and shaded leaves and using canopy architectural parameters is possible (Chen et al., 2003).

Species distribution modelling which is commonly based on ecological models has been shown to improve when incorporating spatio-temporal information derived from optical RS (Pearson, 2007). Recent work in this area (Cord et al., 2009) has shown that analytical techniques that exploit data beyond their spectral dimension to gather knowledge about phenological cycles, seasonal, and latitudinal variations over time can contribute to more accurate vegetation type and species diversity determination. This is important for inventories over natural forested areas at regional and local levels. Optical imagery covering the targeted inventory zones should be available over time. Cloud cover can impair this requirement, while radar sensors provide data even under this condition in addition to being potentially able to provide complementary information about forest structure and vegetation water content because of their different physics nature. 


\section{SAR RS}

Microwave RS instruments are synthetic aperture radar (SAR) systems that image an area independently of solar illumination and are not affected by cloudy or dusty conditions as are optical instruments (Freeman, 1996). They operate in longer wavelengths in the optical regions of the electromagnetic spectrum giving different information on the tree canopies. The SAR sensors image the area by transmitting electromagnetic pulses in frequency bands between 1 and $100 \mathrm{GHz}$. The corresponding wavelength $(\lambda)$ ranges between $1 \mathrm{~mm}$ and $1 \mathrm{~m}$. It is of the same order of magnitude as the sizes of tree leaves, branches and canopies. By comparison, the wavelength of optical instruments ranges from 0.4 to $2.5 \mu \mathrm{m}$, and thus is of the same order of magnitude as the cell components and prevailing pigments of plants (Leblon \& LaRocque 2008). Thereby, optical imagery is more suitable for determining tree canopy biochemistry and inferring vegetation condition, while radar images are better for determining canopy structural parameters

SAR sensors were first developed for military applications. The current satellite civil SAR sensors use one of the following bands: X-band: $12.5-8 \mathrm{GHz}(\lambda: 2.4$ to $4.8 \mathrm{~cm})$ (TerraSAR-X); C-band: 8.0-5.0 GHz ( $\lambda: 4.8-7.5)$ (ERS1/2, ENVISAT, RADARSAT-1/2); and L-band: 2.0-1.0 GHz ( $\lambda:$ 15.0-30.0) (JERS and ALOS-PALSAR). A satellite SAR sensor called BIOMASS operating in the P-band (1.0-0.3 GHz or $\lambda: 30.0-100.0)$ is in preparation by the European Space Agency. It is designed for forestry applications. As detailed in Leblon and LaRocque (2008), microwave radiations which encounter natural surfaces are either:

(i) diffusely scattered towards the sensor to produce the backward scattering called radar backscatter or radar return ( $\sigma^{0}$ sigma nought $)$ which is the only scattering measured by the sensor;

(ii) diffusely transmitted to lower layers through forward scattering;

(iii) specularly reflected in the case of smooth surfaces.

The interactions between microwave radiations and natural surfaces depend on: (i) geometrical factors like the surface roughness as well as the incidence angle and the wavelength of the incident radiation and (ii) dielectric factors which are related to the nature and the moisture content of the target.

Because of the longer wavelength than the one for optical sensors, microwave radiation produces not only surface scattering, but also volume scattering. The intensities of both scatterings depend on the surface roughness, the incidence angle and the wavelength of the incident radiation. Volume scattering also depends on the penetration depth -a function of the wavelength- and occurs when the wave encounters dielectric discontinuities within the material of the target (Leblon \& La Rocque 2008).

Radar backscatter is rather complex on tree canopies. Ulaby et al., (1990) identified eleven components of the radar backscatter of tree canopies. Fig. 1 shows nine major backscattering sources for tree canopies (Piwovar, 1997): 1- Diffuse scattering from the ground; 2- and 3Direct scattering from various vegetation components; 4- Double- bounce vegetationground interaction; 5- Corner reflector between tree trunks and ground; 6- Direct backscatter from the forest canopy; 7- Volume scattering from within the forest canopy; 8Diffuse scattering from the ground; 9- Shadowing by parts of the forest canopy of other parts of the canopy or ground.

The importance of each of the above components on the total scattering of a tree canopy depends mostly on the microwave wavelength (Leblon \& LaRocque, 2008). Radar 
backscatter in shorter wavelengths, like X- and C-band, is mainly due to smaller tree elements (leaves or needles and small branches of the upper tree crown level) (Hoekman 1993); (Mougin et al., 1993); (Yatabe \& Leckie, 1995); (Ahern et al., 1995). Therefore, shortwave bands (X- or C-band) can be used to discriminate between forest species (Drieman et al., 1989); (Hoekman, 1990); (Dobson et al., 1992a); (Mougin et al., 1993); (Rignot et al., 1994a); (Yatabe \& Leckie, 1995); (Ahern et al., 1993, 1995). In particular, the C-band backscatter magnitude of red pine, jack pine and black spruce was found to be inversely related to needle length (Ahern et al., 1993); (Yatabe \& Leckie, 1995). Radar backscatter of longer wavelengths ( $\mathrm{P}$ - and L-bands), which are more penetrating, originates from the major branches of the crown, from the trunks, the double bounce scattering from the tree trunk or crown to ground and from the ground (Richards et al., 1987); (Le Toan et al., 1992); (Hoekman 1993); (Ahern et al,. 1995).

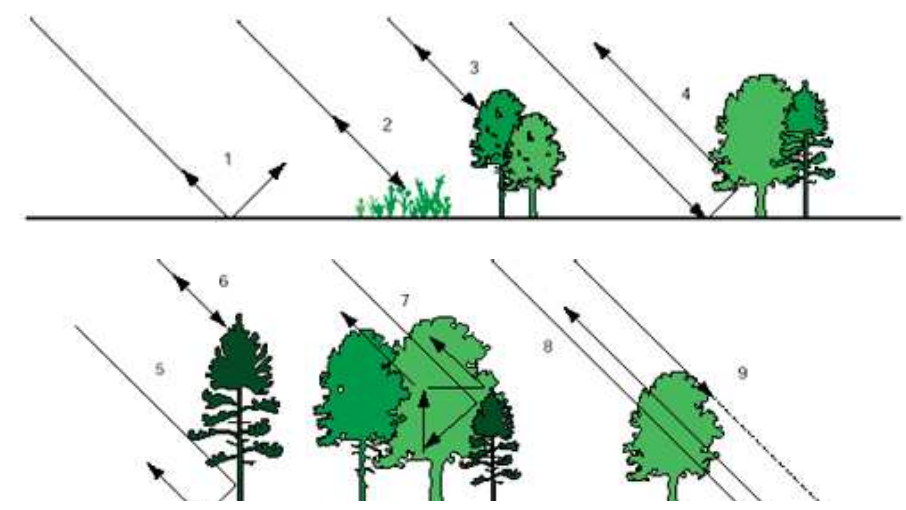

1 Diffuse scattering from the ground; 2 and 3 Direct scattering from various vegetation components; 4 Doublebounce vegetation-ground interaction; 5 Corner reflector between tree trunks and ground; 6 Direct backscatter from the forest canopy; 7 Volume scattering from within the forest canopy; 8 Diffuse scattering from the ground; and 9 Shadowing by parts of the forest canopy of other parts of the canopy or the ground.

Fig. 1. Surface and volume scattering of a SAR beam for trees (Piwowar, 1997).

According to Leblon et al. (2002), radar backscatter $\left(\sigma^{0}\right)$ measurements of forested areas depend on (i) vegetation type, species, and structure (Leckie, 1990); (Dobson et al., 1992a; 1992b; 1995), (ii) vegetation biomass (Kasischke et al., 1995); (Harrell et al., 1995; 1997); (Pulliainen et al., 1996); (iii) topography and surface roughness (Shi et al., 1997) and canopy height (Riom \& Le Toan, 1981); (Dobson et al., 1992b); (Harrell et al., 1997); (iv) flooding and the presence/absence of standing water (Hess et al., 1990; (Kasischke \& Bourgeau-Chavez, 1997), and (iv) near-surface soil moisture or fuel moisture (French et al., 1996); (Leblon et al., 2002); (Abbott et al., 2007).

Discrimination between forest and non forest areas as well as estimation of total aboveground forest biomass or stem volume is better achieved using long wave bands (P-band) (Le Toan et al., 1992); (Dobson et al., 1992b); (Koch et al., 1992); (Rignot et al., 1994b); (Rauste et al., 1994); (Ranson \& Sun, 1994); but the relationship has a logarithmic shape showing a saturation of radar backscatter beyond a certain value of biomass. 
SAR sensors acquire images in one single band. By contrast, optical sensors like Landsat-TM acquire images in a multispectral mode, i.e., several images at different wavelengths at the same time. However, radar sensors can acquire images under various incidence angles which might highlight differences. The most recent radar sensors like ENVISAT-1, ALOSPALSAR TerraSAR- $X$, and RADARSAT-2 also allow the acquisition of images under different polarizations.

This will also allow the production of colour composites like for multispectral optical images. The polarization of the transmitted and returned radiation is an important property, which can be used as a target separator in SAR image analyses. Polarization refers to the position of the locus of the electric field vector in the plane perpendicular to the direction of propagation of the radar microwave radiation. Current SAR systems transmit horizontally polarized $(\mathrm{H})$ or vertically polarized $(\mathrm{V})$ EM waves, which upon interacting with a target generate a backscattered wave with a horizontal polarization $(\mathrm{H})$ or a vertical polarization (V).

The possible combinations are (transmit polarization given first): $\mathrm{HH}, \mathrm{VV}, \mathrm{HV}$ and $\mathrm{VH}$. With multi-polarization sensors, the following imaging capabilities are thus possible: single polarization ( $\mathrm{HH}$ or $\mathrm{VV})$, dual polarization ( $\mathrm{HH}$ and $\mathrm{HV}, \mathrm{VV}$ and $\mathrm{VH}$, or $\mathrm{HH}$ and $\mathrm{VV})$; and quad-polarization ( $\mathrm{HH}, \mathrm{VV}, \mathrm{HV}$, and $\mathrm{VH})$. Some multi-polarization sensors (RADARSAT-2, ALOS-PALSAR and TerraSAR-X) have also a polarimetric mode, that provides not only the intensity information in each polarization $(\mathrm{HH}, \mathrm{VV}, \mathrm{HV}$, and $\mathrm{VH})$, but also the phase information. As a result, the complexity of SAR images processing increases with the level of complexity of the polarization information as it is shown in Fig. 2 in the case of the RADARSAT-2 sensor.

The information provided by multi-polarized or polarimetric SAR images has been investigated, either directly with airborne and satellite radar data, or through simulation models, with respect to their ability to discriminate land cover or forest types (Freeman \& Durden, 1998); (Touzi et al., 2004; (Freeman, 2007), to estimate forest growth (e.g., Izzawati et al., 2006), biomass (e.g., Le Toan et al., 1992) or forest architecture (Lucas et al., 2006). Although the anticipated potential of the polarimetric SAR images like those acquired by RADARSAT-2 for mapping forest inventory, clear cuts, fire scars and biomass has been rated as moderate, merging polarimetric SAR data with other data sources is a promising investigation approach (van der sanden et. al., 2005). This is discussed in the following sections of this chapter.

\section{Forest Inventory Research in Mexico Using Optical and SAR Data}

National forest inventories are labour-intensive and costly endeavours in need of advanced technologies to reduce costs and time schedules and to produce information the levels required by all involved actors. The National Forest Inventory (NFI) in Mexico pertains to the federal government and its general terms are regulated by law. The cartographic scale used in the last inventory, NFI 2000, is 1:250000. 


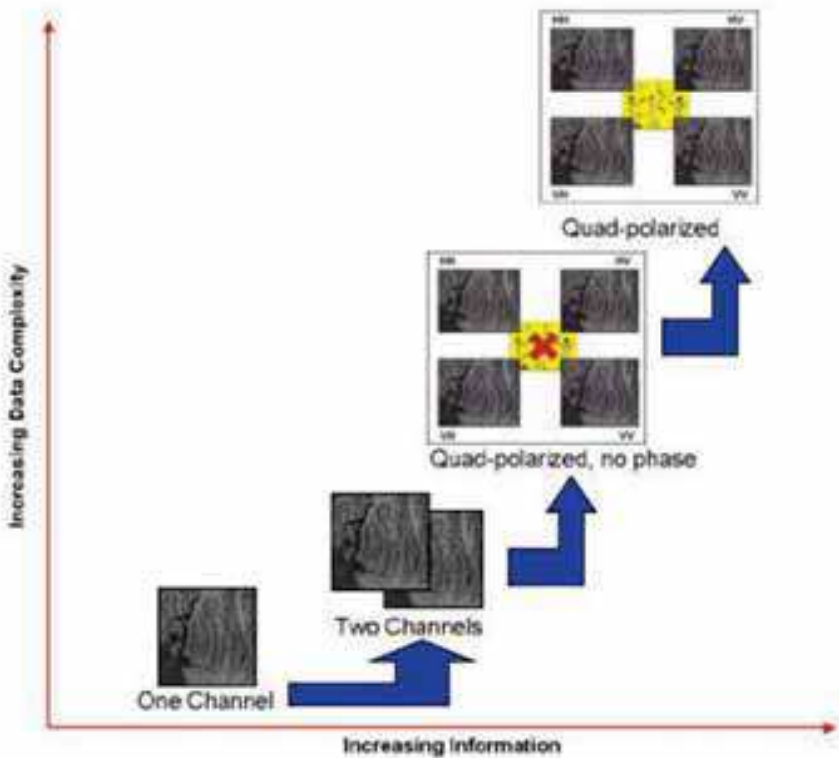

Fig. 2. Information sequence contained in a Radarsat-2 image (courtesy of G. Staples, MDA)

There is, however, a need for establishing more specific forest inventories at the state level, and is the responsibility of state and municipal governments. For the State of Mexico the most recent forest inventory was completed in 1994. The state is located in central Mexico and it contains $75 \%$ of the country's population, and although the physical environment has been modified in recent years there is no up-to-date, reliable, official assessment of forest resources. Information about land cover change has been obtained recently but it is not oriented toward forest inventory (Escalona-Maurice, 2006). Many regions have been transformed by deforestation resulting from various activities including illegal logging, the opening of new agricultural areas, and the development of upper-class residential areas within or near forested regions.

Since 2004, the responsibility for producing an NFI has lain with two government agencies, the National Forestry Commission (CONAFOR) and the Ministry of Environment and National Resources (SEMARNAT). The 2009 inventory will provide valuable forest and soils information but with insufficient detail to adequately support regional or local protection, conservation, and afforestation activities. To our knowledge, there are currently no operational applications of radar RS within Mexican government agencies oriented towards forest inventory or forest management. We consider that SAR and optical RS technologies used together will contribute to satisfying the time requirements, accuracy, and finer levels of detail that are required for forest inventory.

\subsection{Forest Inventory}

In Mexico, as in most countries, forest inventories at different levels of scale are a current concern. There is a worldwide public awareness of the need for sustainable development. However, in developing countries this need is not so easy to meet when faced with other 
immediate priorities and with a scarcity of economic resources. Even so, periodic national information requested by FAO for global forest resource assessments must be provided. At a global level the requirement is for a picture of existing forests, statistics, and derived trends. At the national level the request includes both the country as a whole and the major administrative subdivisions of the territory. Information items include land use and the changes in forested areas, estimates of existence and growth, and diagnosis of the health status of forests. Information about the conservation of natural ecosystems and of biodiversity is also sought (Toledo \& Ordoñez, 1993).

Mexico, with an area of nearly two million $\mathrm{km}^{2}$, is one of three mega-diverse countries (along with the United States and Colombia) with coastlines on the Atlantic and the Pacific. However a growing population and ensuing changes in land use pose many threats to the permanence of this biodiversity, particularly in forested regions. In spite of inadequate funding and technical difficulties due to the extent and varied topography of the country, there has been considerable progress in the construction of the NFI. The last NFI dates back to the year 2000 (Palacio et al., 2000). The cartography was based on a classification scheme based on visual interpretation of Landsat ETM+ colour composite images using the national digital base map. The accuracy assessment was supported with high resolution digital aerial photography. The analysis of deforestation was based on a classification which included four forest classes: (i) primary and secondary tropical and temperate; (ii) scrubland; (iii) man-made covers (grazing land, agricultural cropland, and human settlements); and (iv) other covers (Mas et al., 2002). The NFI 2000 provides the current frame of reference for lower-scale inventories which will be used for the 2009 inventory.

The 2009 inventory, which is $80 \%$ complete in the stratified sample stage and as yet unpublished, will use optical images (AVHRR, MODIS, LANDSAT and SPOT (Sandoval Uribe, 2007). The national mapping scale is being maintained at 1:250000 but a new scale of 1:50000 for reporting at the state level is being adopted. Information will also be reported at the ecological region level, using the official ecological zonification scheme. The results are to be included in a web information system (CONAFOR, 2009). The study area for the investigation reported in this chapter is located approximately within the bounding rectangle of Region 13 Temperate Mountain Areas, which includes the ecosystems of (i) Forest and (ii) High and Medium Jungle, with reported national volume/ha values for these ecosystems of 41.86 and 39.81, respectively (Fig. 3). The preceding discussion motivates and justifies the research project reported in section 4.2.

\subsection{Research Project}

The general research objective of our current research project is to produce a methodology to improve forest inventory assessment and results through the combined use of different sources of data. The methodology should be amenable to translation for use at regional and state levels elsewhere in the country. Particular objectives include the following: (i) to assess the benefits of using polarimetric SAR data in this region, which includes forested areas in the mountain chain "Eje Neovolcánico Transversal"; and (ii) to evaluate techniques for the fusion of optical and SAR data. Part of this project is included in the RADARSAT SOAR \#2755 project. The main objective of the Canadian Space Agency SOAR program is to assess and explore operationally viable solutions to current problems and issues, including those related to the environment. Initiatives include fostering research and development of new 
applications using RADARSAT-2 data, particularly those of fully polarimetric modes (MDA et al., 2009).

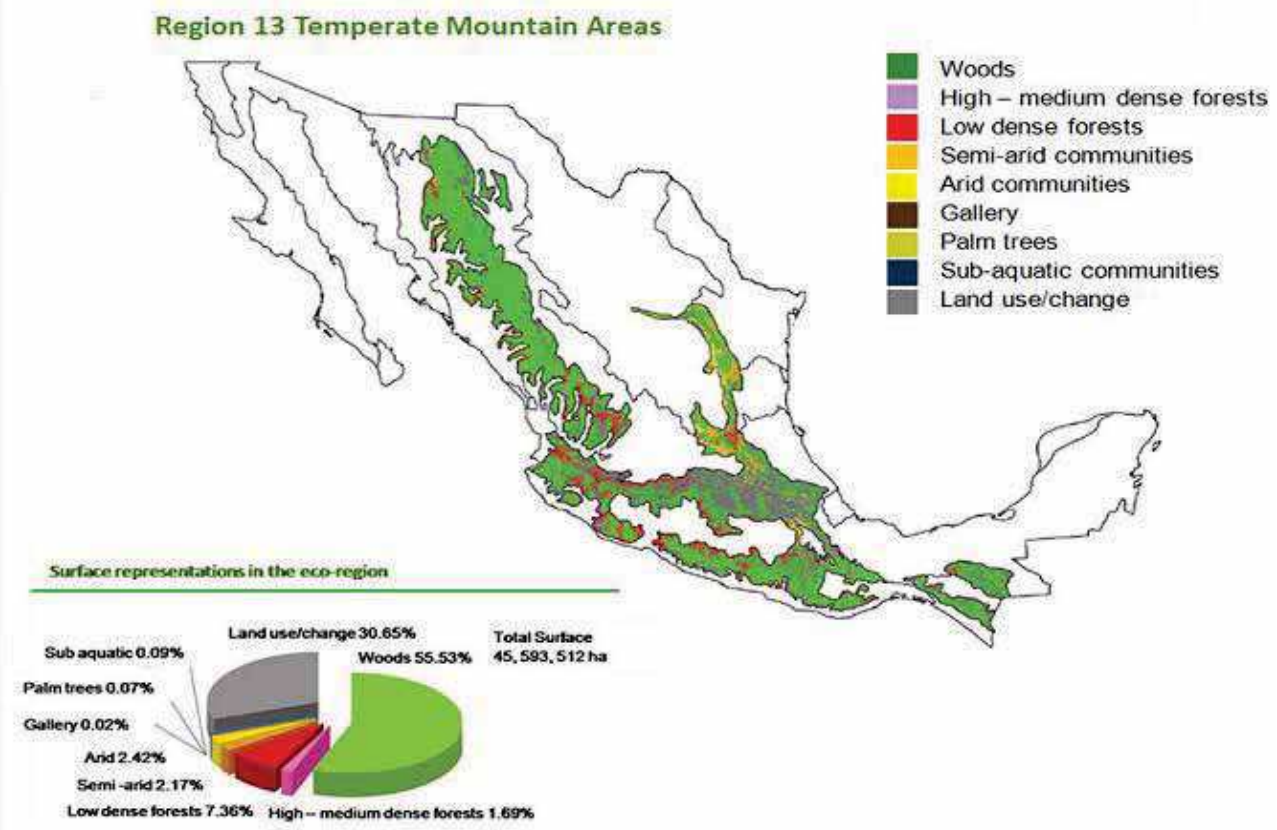

Fig. 3. National Forest Inventory Region 13 Temperate Mountain. (CONAFOR, Mexico)

Although the concept of data fusion is intuitively understood, its exact meaning varies among researchers and among scientific and technological domains. Therefore the term should be formally defined and its various aspects discussed. Fusion has been taken as a synonym of merge, combine, integrate, classify, and synergize. The range of application objectives, methods, and techniques in RS is very diverse, so it is unlikely that a single axis (whether wavelength, acquisition means, image, spatial resolution, mathematical tools, or application domains) can be favoured upon which a fusion definition can be based.

Increased quality of the information is often the goal when using data and information from different sources, but quality in RS depends on the particular objectives to be attained and on whom the end-consumer of the results is. Quality can refer to the enhancement of previous results, of method efficiency, or of results accuracy, all of which are clearly tied to the application and its intended users (Fasbender et al., 2009). Hall and Llinas (1997) (cited by Wald, 1999) consider information quality in terms of "data fusion techniques (that...) combine data from multiple sensors, and related information from associated databases, to achieve improved accuracy and more specific inferences that could be achieved by the use of a single sensor alone."

The notion of the pixel has frequently been used to address data fusion "at the pixel level", but it is often required to consider the merging of information at levels other than the pixel. The information content of a pixel is not comparable in optical and SAR images. Wald (1999) proposed a definition which suits the objectives of this chapter and of our research, since he 
contends that fusion is a framework, not to be confined to the sensors' signals, nor restricted to the peculiarities of the sensor systems: "data fusion is a formal framework for the alliance of data originating from different sources. It aims at obtaining information of greater quality; the exact definition of 'greater quality' will depend upon the application." The processing tools and methods thus comprise no part of this definition of fusion as a framework, even though they are relevant to a particular implementation or methodology of a data fusion effort. The terms "merge" and "combine" are intentionally considered to be looser concepts, allowing for the description of processes and methods in a general way without getting into details. The reader is referred to the ample literature for the ongoing discussion on the definition of the fusion concept and its many and fruitful uses (Pohl \& van Genderen, 1998); (Nikolakopoulos, 2004); (Wang et al., 2005).

Our current work is part of a broader on-going action to map land cover and to assess land cover changes in the State of Mexico (Soria-Ruiz et al., 2009). Forest inventory is an emerging research line within this broader action. Previous related work combined LandsatETM and SPOT producing a map atlas (Soria-Ruiz et al., 2005). The selected study area for this stage of the project is the Zinacantepec Municipality in the State of Mexico. This area is well known from extensive field surveys containing over 60 control points, making it suitable for analyzing natural and deciduous stands (mixed and homogeneous species) and other types of vegetation considered by the national forest inventory. The terrain includes flatland and part of the "Nevado de Toluca" volcano.

Previous tests using Radarsat- 1 data and Landsat-ETM in Central Mexico for land cover in Central Mexico indicated a global map accuracy with optical imagery alone of $78 \%$, whilst fusing optical and SAR resulted in an accuracy of $89 \%$, with a kappa coefficient improvement from 0.72 to $0.86 \%$. So the fusion of Landsat ETM+ and RADARSAT- 1 encouraged more tests of fusion for forest classification and for other land covers as well (Soria-Ruiz \& Fernandez-Ordonez, 2004).

Partial classification results, for four classes, using Landsat ETM images from 2000-2003 are shown in Fig. 4.

The main goals set out for the period 2009-10 using other optical and SAR data are:

(i) Continued update of the land cover map base with high form SPOT, Ikonos, and Quickbird;

(ii) Integration of multi-polarization Radarsat-2 C-band images over the summer and winter seasons to investigate the applicability in this area of $\mathrm{HH}, \mathrm{VV}$, and $\mathrm{HV}$ polarizations. At least six scenes will be used, including polarimetric, fine quad-pol $\mathrm{HH}$ and $\mathrm{VV}$, and $\mathrm{HV}$ and $\mathrm{VH}$;

(iii) Derivation of polarization signatures and relating them to forest parameters for the genera Abies, Pinus, and Quercus, which are largely represented in the area and are of importance for forestry;

(iv) Accuracy assessment of the classifications; and

(v) Assessment of other polarimetric techniques (like interferometry) for different types of stands, including commercial/natural, homogeneous/mixed, and older/younger.

Recent work by Viergever et al., (2007) has investigated biomass estimation for tropical forests in Central America using backscatter and fully polarimetric data from AIRSAR. C-, L-, and P-bands were used; vegetation heights were underestimated due to the heterogeneity of the vegetation cover. In another case, confusion was observed in backscatter values for $\mathrm{P}$ and $\mathrm{L}$ bands for the same type of vegetation (Freeman and Durden 
1998, Freeman 2007). SAR and polarimetric SAR allow using interferometry techniques that are suitable for tree height and density (Papathanassiou \& Cloude 2001). For local forest inventory a high accuracy of classification (on the order of $80 \%$ or better) is desirable. Our work will explore these technical possibilities, and assess their cost-effectiveness, although the long repeat cycle for the satellite overpass leads to de-correlation that restricts the use of such techniques. Since different wavelengths have different penetration properties in forest targets data from other radar sensors such as TerraSAR-X and ALOS-PALSAR (L-band) will also be used.
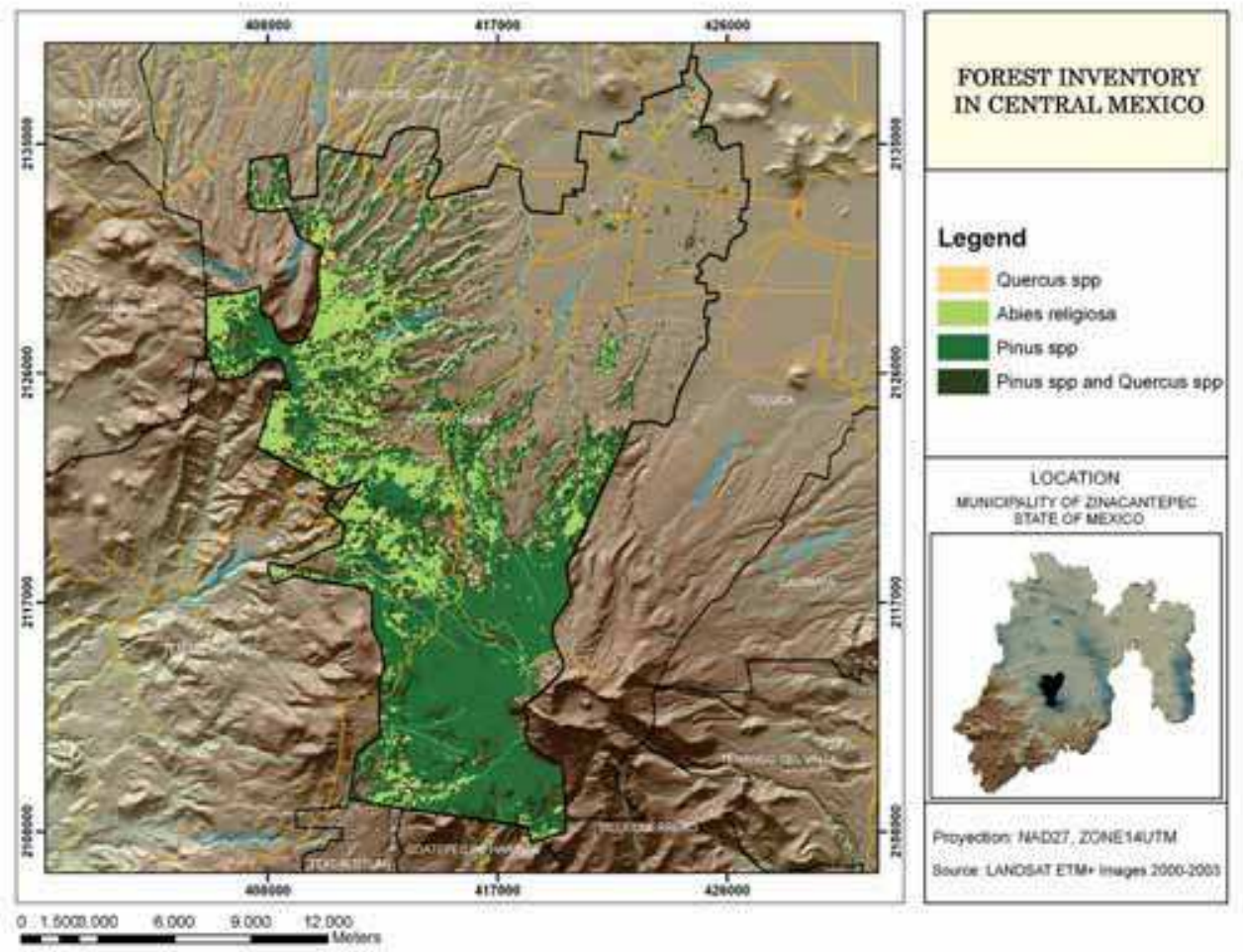

Fig. 4. Forest inventory in the Zinacantepec Municipality, State of Mexico, 2008.

\section{Conclusion}

State and local governments in Mexico have expressed a need for assessment of forest resources at state and municipal level. Bio-conservation and ecological research have data requirements at even smaller cartographic scales, less than 1:10000. Currently, techniques for gathering information at this level are performed on a per-project basis under various limitations and at great cost especially in mountain regions.

The avenue of investigation undertaken in our work is how best to combine optical and SAR RS techniques profiting from the different but complementary information they provide as 
it was shown in the current chapter. Our long term objective is to determine whether polarimetric radar RS in complementary use with optical RS offer conveniences for forest inventory and ecosystem studies in Central Mexico. The study will be based on SPOT, Quickbird and Ikonos images and RADARSAT-2 C-band polarimetric SAR images. These images offer new capabilities in forest inventories, because they are acquired in four polarizations and have the phase information. SAR RF for forests is a challenging research field with many unsolved issues pertaining to forest inventories in mega-diverse areas. Our long term objective is to determine what contribution SAR RS is able to make with respect to forest inventory and ecosystem studies in Central Mexico. However, it has been shown that an even better SAR sensor for forestry applications should operate in the P-band, like the BIOMASS sensor that is currently designed by the European Space Agency. Further projects will be undertaken once the images from this new satellite will become available. Also, interferometry and polarimetric interferometry have been shown to be well suitable for tree height and canopy density measurements from SAR images. Such techniques will be more efficient once images from the new German satellite system called TANDEM-X will be available. The system allows acquiring two images on the same area in almost the same time allowing computing interferograms without temporal decorrelations

\section{References}

Abbott, K.N.; Leblon, B; Staples, G.C.; Maclean, D.A. \& Alexander, M.E. (2007). Fire danger monitoring using RADARSAT-1 over northern boreal forests. International Journal of Remote Sensing. Vol. 28 , Issue 6 (March 2007). 1317-1338. ISSN 0143-1161.

Ahern, F.J.; D.G.; Leckie \& J.A. Drieman, J.A. (1993). Seasonal changes in relative C-band backscatter of Northern forest cover types, IEEE Transactions on Geoscience and Remote Sensing, Vol. 31, Issue. 3, (May 1993). 668-680, ISSN 0196-2892.

Ahern, F.J.; Landry, R.; Paterson, J.S.; Boucher, D. \& McKirdy, I. (1995). Forest land cover information content of multi-frequency multi-polarized SAR data of a boreal forest, Proc. 17th Canadian Symposium on Remote Sensing, June 1995, Saskatoon, Saskatchewan, Canada, 537-549. ISSN 1712-7971.

Aguirre-Salado, C.A.; Valdez-Lazalde, J.R.; Angeles-Perez, G.; De Los Santos-Posadas, H.M.; Haapanen, R. \& Aguirre-Salado, A.I. (2009). Mapping aboveground tree carbon in managed patula pine forests in Hidalgo, Mexico. Agrociencia, Vol 43, (FebruaryMarch 2009), 209-220, ISSN 1405-3195.

Bannari, A.; Morin, D.R.; Huete A.R. \& Bonn, F. (1995). A review of vegetation indices, Remote sensing reviews, No. 13, 95-120. ISSN 0275-7257.

Chen, J.M.; Liu, J.; Sylvain G.; Leblanc, S.G.; Lacaze, R. \& Roujean, J.L. (2003). Multi-angular optical remote sensing for assessing vegetation structure and carbon absorption. Remote Sensing of Environment, Vol. 84, Issue 4 (April 2003) 516-525, ISSN 0034-4257.

CONAFOR, Mexican National Forestry Commission. (2009). National Forest Inventory System SNIF. Accesed 19.02.09

http://148.223.105.188:2222/gif/snif_portal/index.php?option=com_content\&task $=$ view \&id=4\&Itemid $=59$

Conservation International (Content Partner). Mark McGinley (Topic Editor). (2008). Biological diversity in the Madrean pine-oak woodlands.0020 In: Encyclopedia of Earth. Eds. Cutler J. Cleveland (Washington, D.C.: Environmental Information Coalition, 
National Council for Science and the Environment). First published in the Encyclopedia of Earth May 3, 2007; Last revised August 22, 2008; Accessed 02.01 .09 http://www.eoearth.org/article/Biological_diversity_in_the_Madrean_pineoak_woodlands

Cord, A.; Schmidt, M. \& Dech, S. (2009). Potential and limitations of multi-temporal Earth observation data to improve modeled results of tree species distribution in Mexico. Proceedings of 33rd International Symposium on Remote Sensing of the Environment, May 4-8, 2009, Stresa, Lago Maggiore, Italy.

DeFries, R.; Achard, F.; Brown, S.; Herold, M.; Murdiyarso, D.; Schlamadinger, B. \& De Souza, C. Jr. (2006). Reducing Greenhouse Gas Emissions from Deforestation in Developing Countries: Considerations for Monitoring and Measuring. Global Observation of Forest and Land Cover Dynamics. Report Series GOFC-GOLD-34, (August 2006). Vol. 29, No. 5 (October 2003) 633-649, ISSN 1712-7971.

Dobson, M.C.; Pierce, L.; Sarabandi, K.; Ulaby, F.T. \& Sharik, T. (1992a). Preliminary analysis of ERS-1 SAR for forest ecosystem studies, IEEE Transactions on Geoscience and Remote Sensing, Vol. 30 Issue 2, (March 1992) 203-210. ISN 0196-2892.

Dobson, M.C.; Ulaby, F.T.; Le Toan, T.; Beaudoin, A. \& Kasischke, E.S. (1992b). Dependence of radar backscatter on coniferous forest biomass, IEEE Transactions on Geoscience and Remote Sensing, Vol. 30, Issue 2 (March 1992) 412-416. ISSN 0196-2892.

Dobson, M. C.; F. T. Ulaby, \& L. E. Pierce, (1995). Land-Cover Classification and Estimation of Terrain Attributes Using Synthetic Aperture Radar. Remote Sensing of Environment, Vol. 51, No. 1, (January 1995) 199-214, ISSN 0034-4257.

Drieman, J.A.; Leckie, D.G. \& Ahern, F.J. (1989). Multitemporal C-sar for forest typing in Eastern Ontario, Proceedings IEEE International Geoscience and Remote Sensing Symposium IGARSS'89 \& 12th Canadian Symposium on Remote Sensing, Vol. 3, 1376 1378, Vancouver, British Columbia, Canada, July 1989.

Drieman, J.A.; Ahern, F.J. \& Corns, I.G.W. (1989). Visual interpretation of multipolarization C-sar imagery of Alberta Boreal Forest, Proceedings IEEE International Geoscience and Remote Sensing Symposium IGARSS'89 \& 12th Canadian Symposium on Remote Sensing, Vol. 3, 1401-1405, Vancouver, British Columbia, Canada, July 1989.

Escalona-Maurice, M.J. (2006). Landscape of the Texcoco Municipality: morphological and functional analysis in a cartographic model framework. State of Mexico. Mexican United States. (In Spanish: El Paisaje del Municipio de Texcoco: análisis morfológico y funcional en el marco de un modelo cartográfico. Estado de México. Estados Unidos Mexicanos). Doctoral thesis. Departamento de Geografía, Universidad de Alcalá, España. 529 p.

Freeman, A. (2007) Fitting a two-component scattering model to polarimetric SAR data from forests. IEEE Transactions on Geoscience and Remote Sensing, Vol. 45, Issue 8, (August) 2583 - 2592. ISSN 0196-2892.

Harrell, P.A.; Bourgeau-Chavez, L.L.; Kasischke, E.S.; French, N. H. F. \& Christensen, N.L. (1995). Sensitivity of ERS-1 and JERS-1 radar data to biomass and stand structure in Alaskan boreal forest, Remote Sensing of Environment, Vol. 54, Issue 3 (December 1995) 247-260, ISSN 0034-4257.

Harrell, P.A.; Kasischke, E.S.; Bourgeau-Chavez, L.L.; Haney, E. \& Christensen, N.L. (1997). Comparison of approaches to estimate of aboveground biomass in southern pine 
forests using SIR-C data, Remote Sensing Environment. Vol. 59, Issue 3 (February 1997) 223-233. ISSN 0034-4257.

Hess, L.; Melack, J.M. \& Simonett, D.S. (1990). Radar detection of flooding beneath the forest canopy, International Journal of Remote Sensing Vol. 11, No. 7, 1313-1325. ISSN 0143-1161.

Hoekman, D.H. (1990). Radar remote sensing data for applications in forestry, Ph.D. thesis, Wageningen Agricultural University, The Netherlands, $277 \mathrm{p}$.

Hoekman, D.H. (1993) Radar signature and forest vegetation, In: Land Observation by Remote Sensing: Theory and Applications, J.G.P.W. Clevers and H.J. Buiten and (Eds), Current Topics in Remote Sensing, vol.3, Gordon and Breach Science Pub. Ch. 11, 219-235. ISBN 2-88124-939-6, New York, NY, USA.

Kasischke, E. \& Bourgeau-Chavez, L. (1997). Monitoring South Florida wetlands using ERS1 SAR imagery. Photogrammetric Engineering and Remote Sensing, Vol. 63 No. 3, (MONTH) 281-291. ISBN 0099-1112

Kasischke, E.S.; Christensen, N.L. Jr. \& Bourgeau-Chavez, L.L. (1995). Correlating radar backscatter with components of biomass in loblolly pine forests, IEEE Transactions on Geoscience and Remote Sensing, Vol. 33, Issue 3 (May 1995) 643-659, 1995. ISSN 0196-2892.

Koch, B.; Foerster, B. \& Ammer, U. (1992). The use of polarimetric radar remote sensing for application in forestry, Proc. European Int. Space Year Conf. "Remote Sensing for Environmental Monitoring and Resource Management", Munich (Germany), April 1992, ESA SP-341, 789-794.

Leblon, B. 1997. Soil and plant optical properties, The Remote Sensing Core Curriculum, vol. 4, module 9, http:// www.r-s-c-c.org/rscc/Volume4/Leblon/leblon.htm

Leblon, B.; Kasischke, E. S.; Alexander, M. E.; Doyle, M. \& Abbott, M. (2002) Fire danger monitoring using ERS-1 SAR images in the case of northern boreal forests.. Natural Hazards, 27, pp. 231-255.

Leblon, B. \& LaRocque, A. (2008). Radar Polarimetry, online course, 11 chapters Accessed 26.09.08 http://extend.unb.ca/oalp/courses/for4304.php

Leckie, D.G. (1990). Advanced in remote sensing technologies for forest surveys and management. Canadian Journal of Forestry Research. 20: 464-483. ISSN 0045-5067.

Le Toan, T.; Beaudoin, A.; Riom, J. \& Guyon, D. (1992). Relating Forest Biomass to SAR Data. IEEE Transactions on Geoscience and Remote Sensing, Vol. 30, Issue 2, (March 1992) 403-411, ISSN 0196-2892.

Lucas, R.M.; Lee, A.C \& Williams, M.L. (2006). Enhanced Simulation of Radar Backscatter From Forests Using LiDAR and Optical Data. IEEE Transactions on Geoscience and Remote Sensing, Vol. 44, Issue 10, (October 2006) 2736-2754. ISSN 0196-2892.

Mas, J.F.; Velázquez, A.; Palacio-Prieto, J.L.; Bocco, G.; Peralta, A. \& Prado, J. (2002). Assessing forest resources in Mexico: Wall-to-wall land use/cover mapping. Photogrammetric Engineering and Remote Sensing, Vol. 68, No 10, (October 2002) 966-968, Accessed 07.04.09 http://www.asprs.org/publications/pers/2002journal/october/

MDA, CSA \& CCRS. (2009). The Science and Operational Applications Research for RADARSAT-2 Program (SOAR). Canada.

Accessed 22.03.09 http://www.radarsat2.info/outreach/soar/index.asp 
Mougin, E.; Lopes, A.; Karam, M.A. \& Fung, A.K. (1993). Effect of tree structure on X-band microwave signature of conifers. IEEE Transactions on Geoscience and Remote Sensing, Vol. 31, Issue 3, (May 1993) 655-667. ISSN 0196-2892.

Myneni, R.B.; Hall, F.G.; Sellers, P.J.; Marshak, A.L. (1995). The interpretation of spectral vegetation indices. IEEE Transactions on Geoscience and Remote Sensing, Vol. 33, Issue 2, (March 1995) 481 - 486, ISSN 0196-2892.

Nikolakopoulos, K.G. (2004). Comparison of four different fusion techniques for IKONOS data. (2004) 1401-1405. Proceedings of IEEE International Geoscience and Remote Sensing Symposium, 2004. IGARSS'04, Vol. 4, 2534 - 2537, ISBN 0-7803-8742-2, Anchorage, Alaska, USA. September 2004.

Packalén, P. \& Maltamo, M. (2008). Estimation of species-specific diameter distributions using airborne laser scanning and aerial photographs. Can. J. For. Res. Vol. 38. (May 2008). 1750-1760, ISSN 1712-7971.

Palacio P. J.L.; Bocco, G; Velázquez, A.; Mas, J.F.; Takaki, F.; Victoria, A.; Luna, L.; Gómez, G.; López, J.; Palma, M.; Trejo, I.; Peralta, A.; Prado, J.; Rodríguez, A.; Mayorga, R. \& González, F. (2000). The Current Condition of Forest Resources in Mexico: Results From the National Forest Inventory (In Spanish). La Condición Actual de los Recursos Forestales en México: Resultados del Inventario Forestal Nacional 2000. Investigaciones Geográficas, Boletín del Instituto de Geografía, UNAM. No. 43: 183-203. ISSN 0188-4611.

Papathanassiou, K.P. \& Cloude, S.R. (2001). Single-baseline polarimetric SAR interferometry, IEEE Transactions on Geoscience and Remote Sensing, Vol. 39, Issue 11 (November 2001) 2352-2363. ISSN 0196-2892.

Pearson, R.G. (2007). Species' Distribution Modeling for Conservation Educators and Practitioners. Synthesis. American Museum of Natural History. Accessed 07.01.08 http://ncep.amnh.org.

Piwowar, J.M.. (1997). Radar Image Characteristics 22. Complex Scattering Examples. Geomatics International, RADARSAT Distance Learning Program. uregina.ca/piwowarj/geog309/21-RadarImagery.pps

Pohl, C. \& van Genderen, J. L. (1998). Multisensor image fusion in remote sensing: concepts, methods and applications, International Journal of Remote Sensing, Vol. 19, No. 5, (March 1998), 823-854. ISSN 0143-1161.

Pulliainen, J.T.; Mikkelä, P.J.; Hallikainen, M. T. \& Ikonen, J.P. (1996). Seasonal dynamics of C-band backscatter with applications to biomasss and soil moisture estimation. IEEE Transactions on Geoscience and Remote Sensing, Vol. 34, Issue 3, (May 1996) 758770. ISSN 0196-2892.

Ranson, K.J. \& Sun, G. (1994). Mapping biomass of a Northern forest using multifrequency SAR data, IEEE Transactions on Geoscience and Remote Sensing, Vol. 32, Issue 2, (March 1994) 388-396. ISSN 0196-2892.

Rauste, Y.; Häme, T.; Pulliainen, J.; Heiska, K. \& Hallikainen, M. (1994). Radar-based forest biomass estimation, International Journal of Remote Sensing, Vol. 15, No. 14, (September 1994) 2797-2808. ISSN 0143-1161.

Richards, J.A.; Sun, G.Q. \& Simonett, D.S. (1987). L-band radar backscatter modeling of forest stands, IEEE Transactions on Geoscience and Remote Sensing, Vol. 25, Issue 4, (July 1987) 487-498. ISSN 0196-2892. 
Ridder, R. M. (2007). Global Forest Resources Assessment 2010- Options and recommendations for a global remote sensing survey of forests. Forest Resources Assessment Programme, Working paper 141, Rome. (March 2007). Accessed 02.02 .09 http://www.fao.org/forestry/fra2010-remotesensing/en/

Rignot, E.; Williams, C.; Way, J. \& Viereck, L. (1994a). Mapping of forest types in Alaskan boreal forests using SAR imagery, IEEE Transactions on Geoscience and Remote Sensing, Vol. 32, Issue 5 (September 1994) 1051-1059. ISSN 0196-2892.

Rignot, E.; Way, J.; Williams, C. \& Viereck, L. (1994b). Radar estimates of above ground biomass in boreal forests of Interior Alaska, IEEE Transactions on Geoscience and Remote Sensing, Vol. 32, Issue 5, (September 1994). 1117-1125. ISSN 0196-2892.

Riom J. \& Le Toan, T. (1981). Relations entre des types de fôrets de pins maritimes et la retrodiffusion radar en bande L, Proceedings of Spectral Signatures of Objects in Remote Sensing Symposium, 455-465, Avignon, France.

Sandoval Uribe, A. (2007). Advances of the National Forest and Soil Inventory 2004-2009. (In Spanish: Avances del Inventario Nacional Forestal y de Suelos 2004 - 2009), Proceedings Convención Nacional de Geografía 2007, 18-20 (April 2007), Guadalajara, Jalisco, Mexico.

Schowengerdt, R.A. Remote Sensing, 2nd ed. (1997). Academic Press, ISBN 0-12-628981-6, San Diego CA., USA.

Shi, J.; Wang, J.; Hsu, A.Y.; O'Neill, P.E \& Engmann, T. (1997). Estimation of bare surface soil moisture and surface roughness parameter using L-Band SAR image data, IEEE Transactions on Geoscience and Remote Sensing, Vol. 35, Issue. 5, (September) 12541265. ISSN 0196-2892.

Shiver, B. D. \& Borders, B.E. (1996). Sampling Techniques for Forest Resource Inventory. John Wiley \& Sons. ISBN-10: 0471109401; ISBN-13: 978-0471109402. New York.

Soria-Ruiz, J.; Fernández-Ordóñez, Y. \& Gonzalez, E. (2005). Atlas Estatal de Uso del Suelo y Vegetación del Estado de México. INIFAP. Mexico. .

Soria-Ruiz, J.; Y. Fernandez-Ordoñez \& I. Woodhouse. Land cover classification using radar and optical images: a case study in Central Mexico. International Journal of Remote Sensing, ISSN 0143-1161. (Accepted in 2008).

Soria-Ruiz, J. \& Y. Fernández-Ordoñez. (2004). Improving Land-use/cover classification in México. Fusing optical and radar microwave images. GIM International, No. 8, Vol. 18, (April 2004) 33-35 ISSN 1566-9076.

Staples, G.; Hornsby, J.; Branson, W.; O'Neill, K. \& Rolland P. (2004). Turning the scientifically possible into the operationally practical: RADARSAT-2 commercialization plan. Technical note. Canadian Journal of Remote Sensing, Vol. 30, No. 3, (June 2004), 408-414. ISSN 1712-7971.

Sun, G. \& Ranson, K.J. (2000). Modeling lidar returns from forest canopies. IEEE Transactions on Geoscience and Remote Sensing, Vol. 38, Issue 6, (November 2000) 2617 - 2626. ISSN 0196-2892.

Toledo V. M. \& Ordóñez, M. J. (1993). The Biodiversity scenario of Mexico: a review of terrestrial habitat. In: Biological diversity of Mexico: origin and distributions. T.P. Ramamoorthy, R. Bye, A. Lott, J. Fa (Ed). 757-777, Oxford University Press, ISBN10: 019506674X, USA. 
Touzi, R.; Landry, R. \& Charbonneau, F.J. (2004). Forest type discrimination using calibrated C-band polarimetric SAR data. Can. J. Remote Sensing, Vol. 30, No. 3, pp. 543-551, ISSN 1712-7971.

Valdez-Lazalde, J.R.; González-Guillén, M. de J. \& De los Santos-Posadas H. M. (2009). Tree crown cover estimation using high resolution multispectral satellite images. Agrociencia, Vol 43, (May-June), 383-394, ISSN 1405-3195.

van der Sanden, J.J.; Thomas, S.J.; Lukowski, T.I.; Charbonneau, F.J.; DeAbreu, R.; Hawkins, R.K.; Livingstone, C.E.; McNairn, H.; Scheuchl, B.; Singhroy, V.; Toutin, T.; Touzi, R.; Vachon, P.W. (2005). Applications potential of RADARSAT-2 - update. Proceedings of IEEE International Geoscience and Remote Sensing Symposium, 2005. IGARSS'05, Vol. 1, 25-29, ISBN: 0-7803-9050-4, Seoul, South Korea.

Viergever, K.M.; Woodhouse, I.H. \& Stuart, N. (2007). Backscatter and Interferometry for Estimating Above- ground Biomass in Tropical Savanna Woodland. Proceedings of IEEE International Geoscience and Remote Sensing Symposium 2007 IGARSS'07, 23462349. ISBN 978-1-4244-1211-2, Barcelona, Spain.

Vuolo, F.; Dini, L. \& D'Urso, G. (2008). Recent Advances in Quantitative Remote Sensing: Second International Symposium, 25th-29th September 2006, Torrent, Spain. International Journal of Remote Sensing, Vol. 29, Issue 17-18 (September 2008) Pages 5063-5072. ISSN 0143-1161.

Wald, L. Some Terms of Reference in Data Fusion. (1999). IEEE Transactions on Geoscience and Remote Sensing, Vol. 37, No. 3, (May 1999) 1190-1193. ISSN 0196-2892.

Wang, Z.; Ziou, D.; Armenakis, C.; Li, D. \& Li, Q. (2005). A comparative analysis of image fusion methods, IEEE Transactions on Geoscience and Remote Sensing, Vol. 43, Issue 6, (June 2005) 391- 1402, ISSN 0196-2892.

Yatabe, S.M. \& Leckie, D.G. (1995). Clearcut and forest-type discrimination in satellite SAR imagery, Can. J. Remote Sensing, 21(4): 455-467.

Zheng, G.; Chen, J.M.; Tian, Q.J.; Ju, W.M. \& Xia, X.Q. (2007). Combining remote sensing imagery and forest age inventory for biomass mapping. Journal of Environmental Management 85, Issue 3 (November), 616-623, ISSN 0301-4797. 
Advances in Geoscience and Remole Sensing

Advances in Geoscience and Remote Sensing

Edited by Gary Jedlovec

ISBN 978-953-307-005-6

Hard cover, 742 pages

Publisher InTech

Published online 01, October, 2009

Published in print edition October, 2009

Remote sensing is the acquisition of information of an object or phenomenon, by the use of either recording or real-time sensing device(s), that is not in physical or intimate contact with the object (such as by way of aircraft, spacecraft, satellite, buoy, or ship). In practice, remote sensing is the stand-off collection through the use of a variety of devices for gathering information on a given object or area. Human existence is dependent on our ability to understand, utilize, manage and maintain the environment we live in - Geoscience is the science that seeks to achieve these goals. This book is a collection of contributions from world-class scientists, engineers and educators engaged in the fields of geoscience and remote sensing.

\section{How to reference}

In order to correctly reference this scholarly work, feel free to copy and paste the following:

Yolanda Fernandez-Ordonez, Jesus Soria-Ruiz and Brigitte Leblon (2009). Forest Inventory using Optical and Radar Remote Sensing, Advances in Geoscience and Remote Sensing, Gary Jedlovec (Ed.), ISBN: 978-953307-005-6, InTech, Available from: http://www.intechopen.com/books/advances-in-geoscience-and-remotesensing/forest-inventory-using-optical-and-radar-remote-sensing

\section{INTECH}

open science | open minds

\section{InTech Europe}

University Campus STeP Ri

Slavka Krautzeka 83/A

51000 Rijeka, Croatia

Phone: +385 (51) 770447

Fax: +385 (51) 686166

www.intechopen.com

\section{InTech China}

Unit 405, Office Block, Hotel Equatorial Shanghai

No.65, Yan An Road (West), Shanghai, 200040, China

中国上海市延安西路65号上海国际贵都大饭店办公楼 405 单元

Phone: +86-21-62489820

Fax: +86-21-62489821 
(C) 2009 The Author(s). Licensee IntechOpen. This chapter is distributed under the terms of the Creative Commons Attribution-NonCommercial-ShareAlike-3.0 License, which permits use, distribution and reproduction for non-commercial purposes, provided the original is properly cited and derivative works building on this content are distributed under the same license. 